\title{
CAN BE PARENTAL KIMBERLITE MELTS ALKALI-CARBONATE LIQUIDS: RESULTS INVESTIGATIONS COMPOSITION MELT INCLUSIONS IN MANTLE XENOLITHS FROM KIMBERLITES
}

\author{
A.V. Golovin ${ }^{1}$, I.S. Sharygin ${ }^{1}$, A.V. Korsakov ${ }^{1}$ and N.P. Pokhilenko ${ }^{1}$ \\ 1. Sobolev Institute of Geology and Mineralogy, Novosibirsk, Russia (avg@igm.nsc.ru).
}

\section{INTRODUCTION}

Recovery of mantle-derived melt compositions usually based on results of bulk-rock analyses of lavas, erupted at the Earth's surface, or intrusive magmatic rocks. Often these lavas and rocks compositions attributed to composition of parental melts. However liquation, crystallization differentiation and assimilation of crustal and mantle xenoliths are very likely during uplift of the melts. Secondary alterations of the rocks are further puzzling the problem of reconstruction of the melt compositions. All these processes can drastically change the initial compositions of matle-derived melts, and also can be accompanied by replacement of primary mineral assemblages by secondary one in the rocks.

Study of melt inclusions, occurring in minerals from mantle xenoliths, is alternative source of information for reconstruction of mantle-derived melt compositions. The origin of these inclusions can be related to mantle metasomatic processes, partial melting or interaction of minerals with transporting melts, but in any case they represent isolated microportion of mantle melts (see reviews e.g. Schiano, Clocchiatti, 1994; Andersen et. al, 2001; Frezzotti, 2001; Golovin et al., 2007). Since the hostminerals is a good container the problems related with secondary alteration of melt composition can be avoided.

In this paper we present the results of the study of melt inclusions in minerals from the one of the deepest mantle xenoliths - sheared garnet-bearing peridotite (Fig 1). P-T conditions of the origin of these xenoliths estimated as high as $6.0-7.3 \mathrm{GPa}$ and $1230-1370{ }^{\circ} \mathrm{C}$. Detail description of the chemical compositions of the xenoliths can be found elsewhere (Agachev et al., 2010).

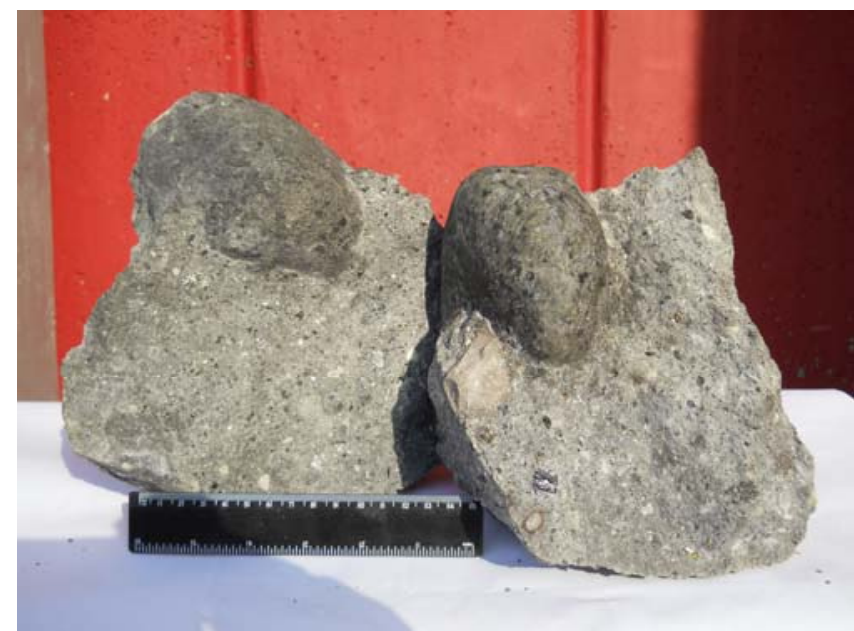

Fig 1. Samples of sheared garnet-bearing peridotite from unique ultra-fresh «salty» kimberlite from Udachnaya East pipe (see Kamenetsky et al., 2007, 2012)

\section{MELT INCLUSIONS}

Secondary melt inclusions (up to 100 microns in size), consisting of bubbles and fine-grained aggregate of carbonates, sulphates and chlorides, as well as transparent daughter phases and ore minerals, were identified in sealed cracks in rock-forming olivine and clinopyroxene (Fig. 2). The daughter phase is generally very small (less than 20 microns in size) and often can escape together with finegrained aggregates. Furthermore some of daughter phases are strongly hygroscopic and interacted with atmosphere. Therefore one of the main task of the paper was identification of mineral composition of intact inclusions bynon-destructive methods (e.g. Raman spectroscopy). Scanning Electron Microscopy (SEM) and Electron Micro Probe Analyses (EMPA) were used for further identification of mineral compositions. Carbonates: northupite, shortite, nyerereite, $\mathrm{Na}-\mathrm{Mg}$-carbonates, 


\section{$10^{\text {th }}$ International Kimberlite Conference, Bangalore - 2012}

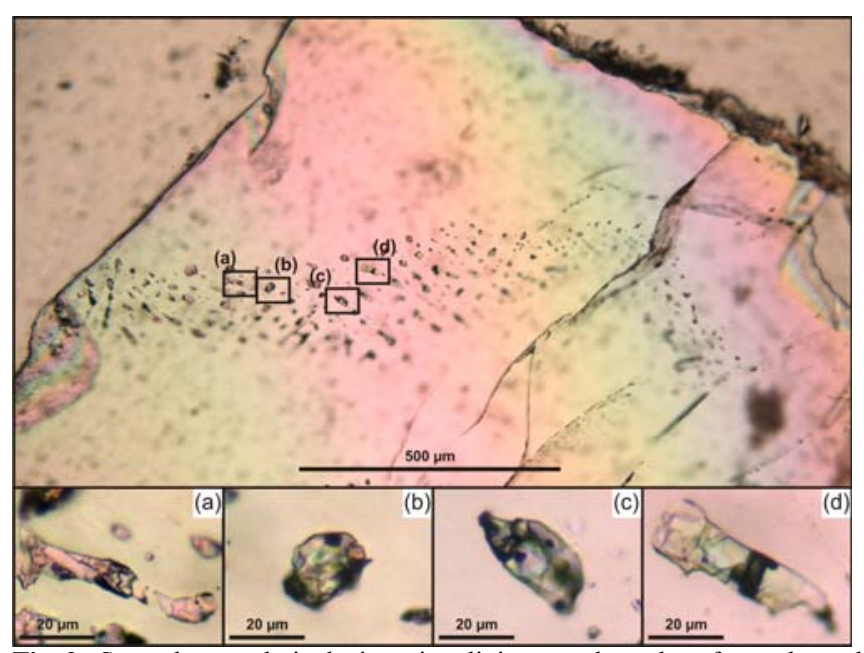

Fig 2. Secondary melt inclusions in olivine porphyroclast from sheared lherzolite xenolith. a-d - individual melt inclusions.

Ba-Na-Sr-carbonates, dolomite, aragonite, calcite; sulfates: burkeite, aphtitalite; chlorides: halite, silvine, chlorinemagnezite; sulfides: pyrrhotite, pentlandite, djerfisherite, KFe sulfide (possible rasvumite?); phosphates: apatite; oxides: perovskite, chromite, magnetite, ilmenite; silicates: phlogopite, tetraferriphlogopite, olivine, diopside, sodalite were identified among daughter phases within the inclusions (Fig 3).
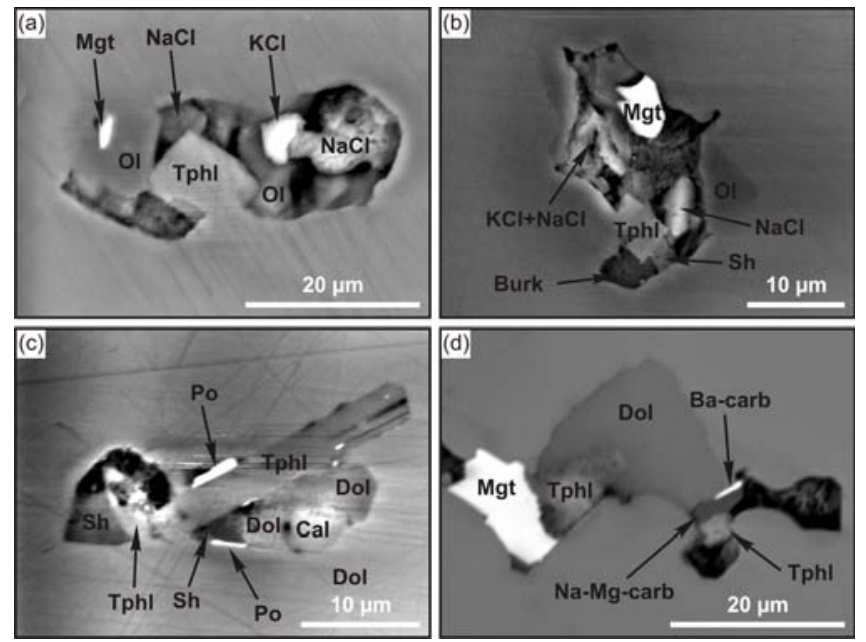

Fig. 3. BSE images of daughter phases from melt inclusions. Ol - olivine, Tphl - tetraferriphlogopite, $\mathrm{Mgt}$ - magnetite, $\mathrm{NaCl}$ - halite, $\mathrm{KCl}$ - silvine, $\mathrm{Sh}$ - shortite, Burk - burkeite, Dol - dolomite, Cal - calcite, Po - pyrrhotite.

Homogenisation tempereature is as high as $800{ }^{\circ} \mathrm{C}$. This temperature estimates is the lowest temperature of the meltmantle xenolith interaction. It is worth noted that both calcite and aragonite was identified in the inclusions. Their chemical compositions were constrained by EMPA. While Raman spectroscopy was used to distinguish the polymorph modification of $\mathrm{CaCO}_{3}$. In mantle xenolith aragonite was identified by presence of main bands at 153, 181, 208, 703, $1086,1464 \mathrm{~cm}^{-1}$ (Fig 4). Main bands at $1086 \mathrm{~cm}^{-1}$, and 283
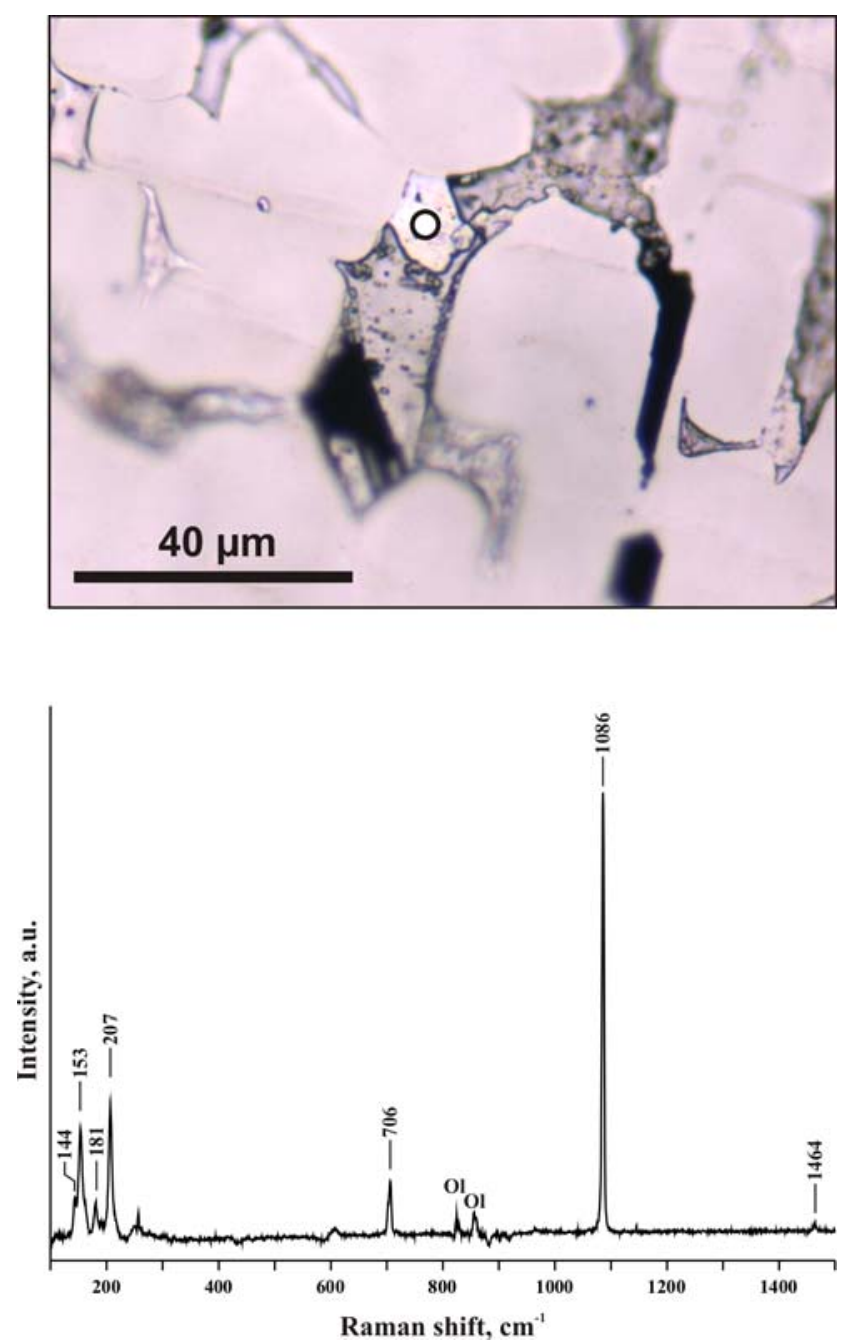

Fig. 4. Representative Raman spectra of aragonite from melt inclusion,

$\mathrm{cm}^{-1}$ were attributed to calcite (e.g. Edwards et al., 2005).

The first finding of aragonite in mantle xenoliths is one of the major point in this study. Experimental investigation (Irving and Wyllie, 1975; Carlson, 1980; Suito et al., 2001) and study of natural samples of ultra-high pressure metamorphic rocks (Hermann et al., 2006; Korsakov and Hermann, 2006; Obrien, 2008; Korsakov et al., 2009) reveal that aragonite is reliable geobarometer. The presence of aragonite in the melt inclusions, considering as relics of the melt, is unequivocal evidence for mantle origin of the melt, excluding contamination of this melt by crustal materials. Thus the presence of aragonite in the inclusions indicates that crystallization of the melt has started at mantle depth, because accordingly to experimental results the pressure of aragonite-calcite equilibrium line should exceed $2 \mathrm{GPa}$ at $800^{\circ} \mathrm{C}$. Higher pressure estimates (as high as $3 \mathrm{GPa}$ ) can be obtained by equilibrium $\mathrm{Mg}$-calcite $=$ aragonite + dolomite, since dolomite was found in the melt inclusions (Fig 5, A). Raman imaging of 10 inclusions reveals that carbonates occupy more than $50 \%$ of inclusion volumes. The alkali- 
carbonates are predominant carbonates within the inclusions, indicating that melt was alkali-carbonate in compositions.

Presence of aragonite and dolomite in the inclusions displays that this melt interact with xenoliths at depth $>90$ km namely mantle depth (Fig. 5, B).
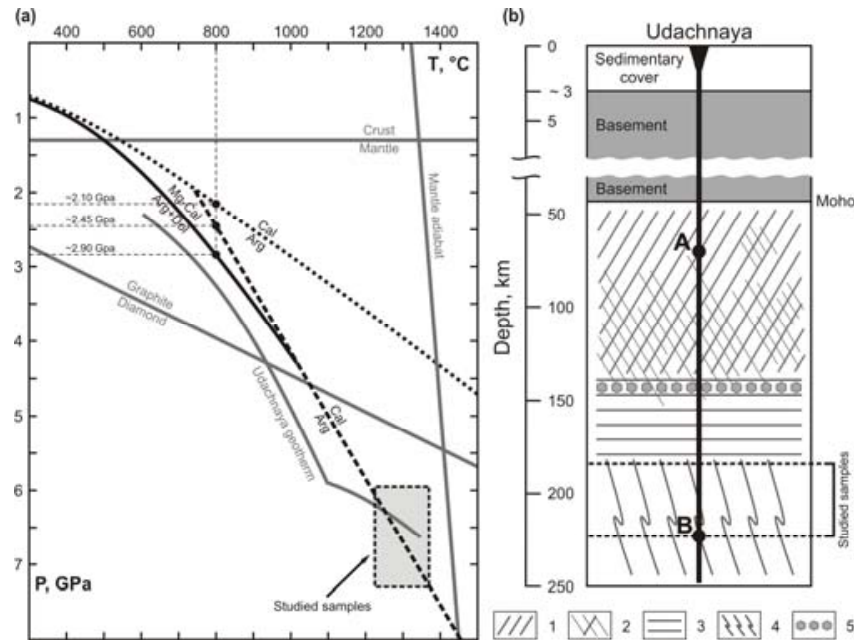

Fig 5. Schemes display the possible depth of entrapment of the melt inclusions. a) P-T diagram with results of temperature homogenization of melt inclusions Calcite $(\mathrm{Cal})-$ Aragonite and $\mathrm{Mg}-\mathrm{Cal}=\mathrm{Arg}+\mathrm{Dol}$ after (Irving, Wyllie 1975; Suito et al., 2001) b) Schematic cross-sections of mantle under Udachnaya kimberlite pipe $\sim 370 \mathrm{Ma}$ after (Pokhilenko et al., 1999) A - B - interval of the depth where melt infiltration in sheared peridoties may occur: A - the minimum depth $\sim 70 \mathrm{~km}$ or $2.1 \mathrm{GPa}$; B - the maximum depth $\sim 225$ км or $7.3 \mathrm{GPa} .1$ - spinel peridotites; 2 - garnetspinel peridotites; 3 - garnet coarse peridotites; 4 - garnet sheared peridotites; 5 - graphite-to-diamond transformation.

\section{DISCUSSION}

Kimberlites are usually considered as mantle rocks and their compositions represent the parental kimberlite melts. $\mathrm{SiO}_{2}, \mathrm{MgO}, \mathrm{CaO}$ and $\mathrm{H}_{2} \mathrm{O}, \mathrm{CO}_{2}$ (up to $90 \%$ in total) are major rock-forming components of kimberlites. The concentration of $\mathrm{SiO}_{2}+\mathrm{MgO}$ in kimberlites may exceed 55 wt.\%. Serpentine (olivine in fresh unaltered samples) and carbonates are the major rock-forming minerals. The serpentine or olivine contents in the kimberlite are generally 50 vol.\% (however in some case it may even exceed 50 vol.\%). Thus presence of olivine or serpentine, which are the main concentrators of $\mathrm{SiO} 2$ and $\mathrm{MgO}$, controls the ultramafic compositions of kimberlites. But this statement is strongly debated now (see review Kamenetsky et al., 2012 submitted). Previous investigation of melt inclusions, which have alkali-carbonatite composition, in olivine from kimberlites (Golovin et al., 2003, 2007; Kamenetsky et al., 2004; 2009 a, 2009 b; Mernagh et al., 2011) and zonation pattern of olivine microphenocryst from kimberlites worldwide make questionable existing paradigm on ultramafic nature of kimberlite magmas.

The study of internal morphology and variation of compositions of microphenocrysts of olivine from unaltered kimberlites reveals that predominant part of olivine cores are xenocrysts and they represent restites of mantle xenolith (Kamenetsky et al., 2008; Brett et al., 2009; Arndt et al., 2010). Brett et al. (2009) suggested that up to $95 \%$ of olivine microphenocrysts in kimberlites are indeed relics of mantle rocks and only about $5 \%$ of olivine grew from kimberlite melt. But this hypothesis is only under development and it requires reliable statistics confirmation.

Results of the melt inclusions study of secondary melt inclusions in minerals from mantle xenoliths display a lot of similarity with previous results on melt inclusions in olivine from kimberlite from Udachnaya East kimberlite pipe (Golovin et al., 2003, 2007; Kamenetsky et al., 2004). Furthermore, chlorides, alkali-carbonates and sulphides were found in ground mass of kimberlites. Concentration of alkalies and $\mathrm{Cl}$ in some samples may exceed 8 and $6 \mathrm{wt.} \%$, respectively (Kamenetsky et al., 2007; Kamenetsky et al., 2012 in press). All this information indicates that there are genetic relations between melts, which interact and sheared lerzolithes, and kimberlite magmatism. We believes that the presence of melt inclusions in the sheared lerzolithes is the first direct evidence that at least on the early stage kimberlite melts had alkali-carbonatite compositions. The kimberlite melts could have alkali-carbonate composition at initial stage of their origin or even during subsequent uplift. There are several factors which could change drastically the chemical composition of kimberlite melt. First of all it is contamination of mantle and crustal materials, as well as secondary alteration processes during interaction of kimberlite melts or kimberlite rocks with ground water or/and atmosphere.

Accordingly experimental study (e.g. Pal'yanov et al., 1999, 2002, 2007; Sokol et al., 2004) the alkali-carbonate systems are good diamond-forming media. Recently, there has been increasing evidence that carbonatite melts/fluids play important role in diamond origin (e.g. Izraeli et al., 2001; Klein-BenDavid et al., 2004; Zedgenizov et al.,2004, 2007; Logvinova et al., 2008; Shatsky et al., 2008; Araujo et al., 2009).

If the protokimberlite melts indeed were alkalicarbonatite melts this rise question that at least some diamond may have close relation with kimberlite magmatism (e.g. Araujo et al., 2009). Findings of the melt inclusions in mineral form one of the deepest mantlederived xenoliths confirm the possibility of generation alkali-carbonatite melts at lithosphere-asthenosphere boundary.

This study was supported by the Russian Foundation for Basic Research (№ 10-05-00575-a). 


\section{References}

Agashev A.M.; Pokhilenko N.P.; Cherepanova Yu.V.; et al. (2010) Geochemical evolution of rocks at the base of the lithospheric mantle: Evidence from study of xenoliths of deformed peridotites from kimberlite of the Udachnaya pipe. Doklady Earth Sciences, v. 432, pp. 746-749.

Andersen T. and Neumann E.-R (2001) Fluid inclusions in mantle xenoliths. Lithos, v. 55, pp. 301-320.

Araujo D.P., Griffin W.L., O'Reilly S.Y., et al. (2009). Microinclusions in monocrystalline octahedral diamonds and coated diamonds from Diavik, Slave Craton: Clues to diamond genesis. Lithos, v. 112S. pp. 724-735.

Arndt N.T., Guitreau M., Boullier A. -M., et al. (2010). Olivine, and the Origin of Kimberlite. J. Petrol., v. 51, pp. 573-602.

Brett R.C., Russell J.K., Moss S. (2009). Origin of olivine in kimberlite: Phenocryst or impostor? Lithos 112S, pp. 201-212.

Carlson, W.D. (1980) The calcite-aragonite equilibrium: effects of $\mathrm{Sr}$ substitution and anion orientation disorder. American Mineralogist, v. 65 , pp. 1252-1262.

Edwards H.G.M., Villar SEJ, Jehlicka J, et al. FT-Raman spectroscopic study of calcium-rich and magnesium-rich carbonate minerals. Spectrochimica Acta Part A, v. 61, pp. 2273-2280.

Frezzotti M.-L. (2001) Silicate-melt inclusions in magmatic rocks: applications to petrology. Lithos, v. 55, pp. 273-299.

Golovin, A.V., Sharygin, V.V., Pokhilenko, N.P., et al. (2003) Secondary melt inclusions in olivine from unaltered kimberlites of the UdachnayaEast pipe, Yakutia. Doklady Earth Sciences, v. 388, pp. 93-96.

Golovin, A.V., Sharygin,V.V., Pokhilenko, N.P. (2007). Melt inclusions in olivine phenocrysts in unaltered kimberlites from the Udachnaya-East pipe, Yakutia: some aspects of kimberlite magma evolution during late crystallization stages. Petrology, v. 15, pp. 168-183.

Golovin A.V. and Sharygin V.V. (2007) Petrogenetic analysis of fluid and melt inclusions in minerals from mantle xenoliths from the Bele pipe basanites (North Minusa depression). Russian Geology and Geophysics, v. 48 , pp. 811-824.

Hermann J, Spandler C, Hack A, et al. (2006) Aqueous fluids and hydrous melts in high-pressure and ultra-high pressure rocks: Implications for element transfer in subduction zones. Lithos, v. 92, pp. 399-417.

Irving, A.J. and Wyllie, P.J. (1975) Subsolidus and melting relationships for calcite, magnesite and the join $\mathrm{CaCO} 3-\mathrm{MgCO} 3$ to $36 \mathrm{kbar}$ Geochimica et Cosmochimica Acta, v. 39, pp. 35-53.

Izraeli E.S., Harris J.W., Navon O. (2001) Brine inclusions in diamonds: a new upper mantle fluid. Earth Planet. Sci. Lett., v. 5807, p. 1-10.

Kamenetsky M.B., Sobolev A.V., Kamenetsky V.S., et al. (2004) Kimberlite melts rich in alkali chlorides and carbonates: A potent metasomatic agent in the mantle. Geology, v. 32, pp. 845-848.

Kamenetsky V.S., Kamenetsky M.B., Sharygin V.V., et al. (2007) Carbonate-chloride enrichment in fresh kimberlites of the UdachnayaEast pipe, Siberia: a clue to physical properties of kimberlite magmas? // Geophys. Res. Lett., v. 34, pp. 9316-9321.

Kamenetsky V.S., Kamenetsky M.B., Sobolev A.V., et al. (2008) Olivine in the Udachnaya-East kimberlite (Yakutia, Russia): types, compositions and origins. J. Petrol., v. 49, pp. 823-839.

Kamenetsky V.S., Kamenetsky M.B., Weiss Y., et al. (2009 a) How unique is the Udachnaya-East kimberlite? Comparison with kimberlites from the Slave Craton (Canada) and SW Greenland. Lithos, v. 112S, pp. 334-346.

Kamenetsky V.S., Maas R., Kamenetsky M.B., et al. (2009 b) Chlorine from the mantle: Magmatic halides in the Udachnaya-East kimberlite, Siberia // Earth Planet. Sci. Lett., v. 285, pp. 96-104.

Kamenetsky V.S., Kamenetsky M.B., Golovin A.V., et al. (2012) Petrology of fresh Udachnaya-East kimberlites: myths and facts about parental kimberlite melt. Lithos, in press.

Klein-BenDavid O., Izraeli E.S., Hauri E., et al. (2004) Mantle fluid evolution - a tale of one diamond. Lithos, v. 77, pp. 243-253.

Korsakov A.V. and Hermann J. (2006) Silicate and carbonate melt inclusions associated with diamonds in deeply subducted carbonate rocks. Earth and Planetary Science Letters, v. 241 pp. 104-118.
Korsakov A.V., De Gussem K., Zhukov V.P. et al. (2009) Aragonitecalcite-dolomite relationships in UHPM polycrystalline carbonate

inclusions from the Kokchetav Massif, northern Kazakhstan. Eur. J. Mineral., v. 21, pp. 1301-1311.

Logvinova A.M., Wirth R., Fedorova E.N., et al. (2008). Nanometre-sized mineral and fluid inclusions in cloudy Siberian diamonds: new insights on diamond formation. Eur. J. Mineral., v. 20, pp. 317-331.

Mernagh, T.P., Kamenetsky, V.S., Kamenetsky, M.B. (2011). A Raman microprobe study of melt Inclusions in kimberlites from Siberia, Canada, SW Greenland and South Africa. Spectrochimica Acta Part A, v. 80 , pp. 82-87.

Obrien P.J. and Ziemann M.A. (2008) Preservation of coesite in exhumed eclogite: insights from Raman mapping. Eur. J. Mineral., v. 20, pp. 827834

Pal'yanov Y.N.; Sokol A.G.; Borzdov Y.M.; et al. (1999). Diamond formation from mantle carbonate fluids. Nature, v. 400, pp. 417-418.

Pal'yanov Y.N., Sokol A.G., Borzdov Y.M., et al. (2002). Fluid-bearing alkaline carbonate melts as the medium for the formation of diamonds in the Earth's mantle: an experimental study. Lithos, v. 60, pp 145-159.

Pal'yanov Y.N., Shatsky V.S., Sobolev N.V., et al. (2007) The role of mantle ultrapotassic fluids in diamond formation. PNAS, v. 104, pp. 9122-9127.

Schiano, P. and Clocchiatti, R. (1994) Worldwide occurrence of silica-rich melts in sub-continental and sub-oceanic mantle minerals. Letters to nature, v. 368, pp. 621-624.

Shatsky V.S., Ragozin A.L., Zedgenizov D.A., et al. (2008). Evidence for multistage evolution in a xenolith of diamond-bearing eclogite from the Udachnaya kimberlite pipe. Lithos, v. 105, pp. 289-300.

Sokol A.G. and Pal'yanov Y.N. (2004). Diamond crystallization in fluid and carbonate-fluid systems under mantle P-T conditions: 2. An analytical review of experimental data. Geochemistry International, v. 42, pp 1018-1032.

Suito, K., Namba, J., Horikawa, et al., (2001) Phase relations of CaCO3 at high pressure and high temperature. American Mineralogist, v. 86, pp. 997-1002.

Zedgenizov D.A., Ragozin A.L., Shatsky V.S. (2007) .Chloride-carbonate fluid in diamonds from the eclogite xenolith. Doklady Earth Science, v. 415, pp. 961-964.

Zedgenizov D.A., Kagi H.K., Shatsky V.S., et al. (2004) Carbonatitic melts in cuboid diamonds from Udachnaya kimberlite pipe (Yakutia) evidence from vibrational spectroscopy, Mineralogical Magazine, v. 68 pp. 61-73. 